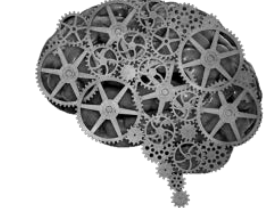

COMPANY GROUP "INTELLEKT"

Фахрутдинова Р.А., Тренгулова С.Ф. Институт экономики, управления и права Казань, Россия

doi: 10.18411/lj2016-5-5-07

\title{
Интерактивный метод как способ формирования иноязычной компетенции студентов в неязыковом ВУЗе
}

В последнее время роль иностранного языка в российском обществе существенно изменилась: значительно повысился его статус. С одной стороны, его стали рассматривать как средство обеспечения успешной жизнедеятельности людей, а с другой стороны - иностранный язык стал одним из важных факторов культурного и социального развития личности.

На сегодняшний день интерактивность понимается как взаимодействие на основе диалога, последовательного обмена информацией в процессе обучения. Для того чтобы смоделировать педагогическую технологию формирования иноязычной компетенции с применением интерактивного метода, необходимо рассмотреть такие понятия как интерактивное обучение и интерактивный метод.

Интерактивный метод - означает взаимодействовать, находиться в режиме беседы, диалога с кем-либо, он ориентирован на более широкое взаимодействие обучающихся не только с преподавателем, но и друг с другом. Эффективность обучения с применением интерактивного метода определяется личностью студента, степенью ее мотивации, системой интерактивных занятий, проводимых в разных формах.

В соответствии с требованиями ФГОС реализация компетентного подхода предусматривает использование различных интерактивных методов проведения занятий, среди которых: 
- метод проектов - один из наиболее эффективных способов организации самостоятельной работы студентов, который применяется на заключительной стадии изучения темы, т. е. в качестве закрепления или в процессе повторения. Данный метод позволяет индивидуализировать процесс обучения, предоставляет возможность обучающимся самостоятельно планировать, осуществлять и контролировать свою деятельность. Используя проектную методику, студенты могут самостоятельно выбирать источники информации, формы презентации материала и проявить в полной мере свои творческие способности. Проектная работа включает несколько этапов. На первом этапе обсуждается содержание и характер проекта, источники и способы нахождения информации, распределяются индивидуальные задания или задания для микрогрупп. Группы формируются согласно уровню владения языком, психологическим особенностям, творческим способностям. На втором этапе ведется работа непосредственно с проектами, а именно: сбор, резюмирование и анализ информации; обмен информацией; составление активного словаря; написание личного проекта; создание слайдов, рисунков, плакатов и т. п. Третий этап — презентация проекта.

- метод учебных групповых дискуссий, с помощью которого приобретаются навыки коллективного взаимодействия и публичного выступления студентов.

- деловая игра - это комплексный методический прием обучения, позволяющий выработать у студентов умение и навыки индивидуального или группового принятия решения поставленных задач.

- круглый стол - обучение в команде, при котором особое внимание уделяется групповым целям и успеху всей группы, достигающимся только в результате самостоятельной работы каждого члена группы в постоянном взаимодействии с другими членами этой группы. 
Интерактивное обучение в процессе занятий предполагает организацию и развитие диалогового общения, которое ведёт к взаимодействию, взаимопониманию, к совместному решению общих задач для каждого обучающегося.

Главная цель интерактивного обучения - целостное развитие личности обучающегося. Средством же развития личности является самостоятельная познавательная и мыслительная деятельность. Следовательно, задача преподавателя - обеспечить на занятии такую деятельность, чему способствуют современные интерактивные методы и технологии.

Усвоение лексического материала осуществляется при взаимодействии студентов с иноязычной лексикой без опоры на текст, с помощью чего минимизируются трудности понимания терминов, также происходит продуктивное усвоение иноязычной профессиональной лексики.

Формирование иноязычной компетентности для студентов неязыковых вузов обеспечивается через содержание обучения. Систематическая работа над улучшением произношения и словарного запаса, междисциплинарные связи с профессиональными предметами способствует овладению студентами языковым компонентом коммуникативной компетенции.

Студенты неязыковых вузов не достаточно владеют иностранным языком как средством профессиональной коммуникации, обучение выстраивается в основном на чтении профильных текстов и построении монологических сообщений по ним. Из контекста обучения выпадают такие значимые и существенные стороны, как умение вести диалог, умение активно слушать профессионально направленную речь, умение строить письменную коммуникацию.

Рассмотрим педагогическую технологию формирования иноязычной компетенции у студентов неязыковых вузов с точки зрения форм организации учебных занятий - как интерактивных аудиторных занятий, так и занятий с использованием компьютера. 
Компьютерные средства обучения называются интерактивными, так как они обладают способностью «откликаться» на действия студента и преподавателя, «вступать» с ними в диалог, предоставлять обучаемому конкретный опыт по усвоению иностранного языка, что и составляет суть интерактивного обучения. При обучении студентов иностранным языкам наиболее эффективными методами являются следующие: мультимедийная презентация, тестирующие интерактивные программы on-line (например, TOEFL), мультимедийные программы, интерактивные доски, кейс-метод (основан на ситуационной методике обучения). Данные методы позволяют достичь следующих целей: доступность восприятия учебного материала, систематизация знаний, развитие творческих способностей обучаемых, самообразование, снятие психологического барьера, осмысление учебного материала и анализ усвоенного материала.

Компьютер может использоваться на всех этапах процесса обучения: при объяснении нового материала, в процессе повторения и контроля знаний, умений и навыков. При этом для обучающихся он выполняет различные функции: преподавателя, рабочего инструмента. В функции преподавателя компьютер представляет источник учебной информации, наглядное пособие (с возможностями мультимедиа), средство диагностики и самоконтроля. В функции рабочего инструмента компьютер выступает как средство подготовки текстов и их хранения, текстовый редактор, средство моделирования. При таком обучении акцент делается на самостоятельную работу, следовательно, проявляется дифференцированный подход к каждому из студентов.

Эффективность формирования иноязычной коммуникативной компетенции будущего специалиста обеспечивается посредством использования различных технологий и методов обучения, адекватно отражающих содержание и структуру иноязычной коммуникативной компетенции будущего специалиста. 


\section{Литература:}

1. Новые педагогические и информационные технологии в системе образования : учеб. пособие для студ. пед. вузов и системы повыш. квалиф. пед. кадров / Е.С. Полат, М.Ю. Бухаркина, М.В. Моисеева, А.Е. Петров; под ред. Е.С. Полат. - М.: Издательский центр «Академия», 2001. $-272 \mathrm{c}$.

2. Петровская Л.А. Компетентность в общении. / Л.А. Петровская - М.: Издво МГУ, 2005.- 216 с. 